\title{
Proses Organisasi Informasi Covid-19 Pada Media Sosial Instagram Kementerian Komunikasi dan Informatika Republik Indonesia
}

\author{
Christin Hani, Roswita Oktavianti \\ christin.915170034@stu.untar.ac.id, roswitao@fikom.untar.ac.id
}

Fakultas Ilmu Komunikasi Universitas Tarumanagara

\begin{abstract}
The Ministry of Communication and Informatics of the Republic of Indonesia (Kemenkominfo) is the official reference in delivering guidance and information about Covid-19. Therefore, the Ministry of Communication and Information carries out an information management process that involves organizational subsections within it. This process is studied using organizational information theory. This research raises the issue of the information organization process carried out by organizational members at the Ministry of Communication and Information in receiving and re-analyzing information related to Covid-19 through three stages of analysis, namely, enactment, selection, and retention. The three stages of information organization aim to reduce equivocality or confusion of information related to Covid-19 received between subsections of the Ministry of Communication and Informatics during the Covid-19 pandemic. This research uses a qualitative approach with a case study method. The case study was conducted in the organization subsection of the Ministry of Communication and Information. Data collection was carried out by interviewing techniques. The results of this study indicate that the Ministry of Communication and Informatics carried out the determination process by interpreting the information between the online media subsection and the news by evaluating the information. Then obtained a policy to receive information from official sources. The information selection process is carried out by looking for additional information on external media, especially Instagram. The last is the process of storing information that has been received, not collected during the process of receiving information. The organization of the Ministry of Communication and Information is more focused on evaluating the information received by way of discussion among other subsections and subsections in order to reduce disinformation.
\end{abstract}

Keyword: digital communication, organizational information theory, social media

\begin{abstract}
Abstrak
Kementerian Komunikasi dan Informatika Republik Indonesia (Kemenkominfo) menjadi rujukan resmi dalam menyampaikan panduan dan informasi seputar Covid-19. Oleh karena itu Kemenkominfo melakukan proses pengelolaan informasi yang melibatkan subbagian organisasi didalamnya. Proses ini dikaji dengan menggunakan teori informasi organisasi. Penelitian ini mengangkat persoalan mengenai proses organisasi informasi yang dilakukan oleh anggota organisasi di Kemenkominfo dalam menerima dan menganalisis kembali informasi terkait Covid-19 melalui tiga tahap analisis yakni, penetapan (enactment), pemilihan (selection), dan penyimpanan (retention). Tiga tahap organisasi informasi tersebut bertujuan untuk mengurangi ekuivokalitas atau kesimpangsiuran informasi terkait Covid-19 yang diterima antar subbagian organisasi Kemenkominfo saat pandemi Covid-19. Penelitian ini menggunakan pendekatan kualitatif dengan metode studi kasus. Studi kasus dilakukan pada subbagian organisasi Kemenkominfo. Pengumpulan data dilakukan dengan teknik wawancara. Hasil penelitian ini menunjukkan Kemenkominfo melakukan proses penetapan dengan cara menginterpretasikan informasi antara subbagian media online dan pemberitaan
\end{abstract}


dengan cara evaluasi informasi. Kemudian diperoleh kebijakan untuk menerima informasi dari sumber resmi. Proses penyeleksian informasi dilakukan dengan cara mencari informasi tambahan di media eksternal khususnya instagram. Terakhir adalah proses penyimpanan informasi yang telah diterima, tidak dikumpulkan saat proses penerimaan informasi. Organisasi Kemenkominfo lebih fokus mengevaluasi informasi yang diterima dengan cara berdiskusi antar sesama subbagian maupun subbagian lainnya agar dapat mengurangi disinformasi.

Kata Kunci: komunikasi digital, media sosial, teori informasi organisasi

\section{Pendahuluan}

Pandemi Coronavirus Disease (Covid-19) yang menyebar di Indonesia pada awal Maret 2020, mengharuskan pemerintah bertindak tegas untuk mencegah penyebaran lebih luas. Gelombang informasi yang simpang siur turut menyertai pandemi virus korona baru (SARS-CoV-2), penyebab penyakit Covid-19, yang telah berlangsung beberapa bulan terakhir. Pemahaman yang keliru mengenai Covid-19 bisa berakibat fatal, dan dalam mendapatkan informasi sebaiknya masyarakat mengikuti panduan atau informasi resmi seperti dari otoritas kesehatan maupun akun resmi pemerintah (Ramadhan, 2020). Salah satunya adalah panduan dan informasi yang resmi seputar Covid-19 pada media sosial akun Instagram Kementerian Komunikasi dan Informatika Republik Indonesia (Kemenkominfo).

Dalam kondisi pandemi Covid-19 seperti sekarang ini, pemberian informasi juga memerlukan pemilihan informasi yang sudah diseleksi (Nindyasari, 2014). Pemilihan informasi Covid-19 yang akan disampaikan pada Kemenkominfo, melalui tahap ini akan ada seleksi dan juga pertimbangan dalam menentukan informasi. Dibutuhkan proses penyeleksian sebelum informasi ditampilkan di media, agar dapat dipilih terlebih dahulu mana yang dibutuhkan dan tidak dibutuhkan. Proses pengelolaan informasi membutuhkan anggota organisasi. Proses penyeleksian inilah yang menggunakan tiga tahapan teori informasi organisasi (Nindyasari, 2014).

Proses informasi organisasi Karl Weick (dalam Suswanto, 2016:3) menjelaskan bahwa seluruh aktivitas berorganisasi merupakan interaksi ganda, dan aktivitas berorganisasi yang dilakukan berperan untuk meminimalisir ketidakpastian, komplikasi, dan ambigu. Weick mengemukakan seluruh informasi yang berasal dari lingkungan sekitar memiliki sifat ambigu dalam beberapa proses informasi. Ketika memperoleh informasi sering kali muncul ketidakpastian didalamnya. Oleh karena itu, dalam meminimalisir ketidakpastian informasi diperlukannya proses pengorganisasian. Peneliti menjelaskan tiga tahapan menganalisis informasi organisasi yakni, Enactment (Penetapan), Selection (Penyeleksian), dan Retention (Penetapan) (West dan Turner, 2009).

Enactment adalah tahap mengurangi ketidakpastian yaitu dengan tahap menerima informasi. Tahap Selection adalah proses anggota organisasi yang memperoleh informasi yang diduga relevan dalam konteksnya dan melakukan penolakan terhadap informasi lainnya yang tidak relevan. Terakhir adalah tahap Retention yang mana organisasi melakukan penyimpanan informasi pada tanggapan dari berbagai situasi. Informasi yang telah disimpan dapat dijadikan satu pada kesatuan informasi yang sudah ada untuk mengendalikan organisasi dan informasi tersebut akan digunakan untuk kasus serupa (Destiana: 41-43).

Penelitian ini dilakukan dengan tujuan untuk mengetahui proses organisasi informasi dilingkungan organisasi Kemenkominfo saat pandemi Covid-19. Oleh 
Christin Hani, Roswita Oktavianti: Proses Organisasi Informasi Covid-19 Pada Media Sosial Instagram Kementerian Komunikasi dan Informatika Republik Indonesia

karena itu, penelitian ini mengangkat judul "Proses Organisasi Informasi Covid-19 Pada Media Sosial Instagram Kementerian Komunikasi dan Informatika Republik Indonesia".

\section{Metode Penelitian}

Metode penelitian yang digunakan peneliti adalah metode kualitatif bersifat deskriptif yang meneliti proses organisasi informasi subbagian organisasi Kemenkominfo saat pandemi Covid-19. Penelitian kualitatif ini menggunakan analisis data induktif. Data yang dimaksudkan adalah berupa teks, ilustrasi, wawancara, dan sebagainya (Creswell, 2007). Penelitian ini menggunakan metode studi kasus.

Studi kasus dalam penelitian ini dilakukan dengan mengkaji sebuah peristiwa atau fenomena yang terjadi pada organisasi dengan Divisi Publikasi dan Pelayanan Informasi Biro Humas Sekretaris Jenderal Kementerian Komunikasi dan Informatika (Kemenkominfo) dalam menyeleksi informasi pada media sosial instagram Kemenkominfo terkait informasi Covid-19. Subjek dalam penelitian ini adalah anggota organisasi pada Divisi Publikasi Subbagian Pemberitaan dan Divisi Pelayanan Informasi Subbagian Media Online Biro Humas Sekretaris Jendral Kementerian Komunikasi dan Informatika (Kemenkominfo). Objek dalam penelitian ini adalah komunikasi antar anggota organisasi yang berfokus pada proses penyeleksian informasi Covid-19 melalui penggunaan media sosial instagram dalam Divisi Humas Subbagian Media Online dan Pemberitaan Kemenkominfo.

Sumber data primer peneliti adalah wawancara kepada Kepala Divisi Publikasi Subbagian Pemberitaan Humas Kemenkominfo, Taufiq bersama Annisa Bonita sebagai Koordinator Humas Divisi Pelayanan Informasi Subbagian Media Online Kemenkominfo. Penelitian ini menggunakan sumber data sekunder seperti jurnal, artikel, dokumen, dan informasi yang sebagian diperoleh dari pihak yang berkaitan dengan proses organisasi informasi Covid-19 pada media sosial instagram Kemenkominfo.

Peneliti menggunakan teknik triangulasi data. Menurut Moleong (2009:330) triangulasi merupakan teknik pemeriksaan keabsahan informasi data yang memanfaatkan sesuatu yang lain diluar data itu untuk keperluan pengecekan atau sebagai pembanding dari berbagai sumber informasi data, hasil dari wawancara yang diperoleh dari partisipan dan sebagainya.

\section{Hasil Temuan dan Diskusi}

Teori informasi organisasi Karl Weick yang merupakan fokus utama pada penelitian ini yang menekankan bahwa pentingnya lingkungan organisasi dalam berkomunikasi. Kreps (dalam Nindyasari 2014:11) mengemukakan bahwa inti dari teori Weick merupakan lingkungan organisasi. Seperti yang diungkapkan Ricard West dan Lynn H. Turner (dalam Oktaviana dan Widayatmoko, 2018:557), komunikasi (communication) adalah sebuah bentuk metode pergantian pesan yang memakai sebuah tanda dalam memperoleh inti pesan yang sesuai dari pengirim kepada penerima pesan pada pernyataan tersebut dikatakan bahwa sebelum menghasilkan suatu output, organisasi harus terlebih dulu melihat komunikasi disekitar lingkungan organisasinya. 
Proses organisasi informasi yang dilakukan oleh Kemenkominfo, dalam berkoordinasi secara digital saat pandemi Covid-19 terdapat banyak perubahan dalam segi berkomunikasi. Faktor utama dari perubahan yaitu faktor eksternal yang merubah cara berkoordinasi menggunakan media digital seperti aplikasi zoom, pesan instant whatsapp dan sebagainya. Dalam proses penerimaan informasi melalui media digital ini terjadi interaksi dan tidak semua anggota organisasi memiliki pendapat yang berbeda-beda yang memunculkan berbagai informasi ambiguitas, sehingga koordinasi yang dilakukan tidak berjalan dengan baik dan tidak efektif ketika memperoleh informasi sering kali muncul ketidakpastian didalamnya. Oleh karena itu, dalam meminimalisir ketidakpastian informasi diperlukannya proses pengorganisasian sebagai berikut:

1. Proses Organisasi Informasi: Penetapan (Enactment)

Pada proses organisasi informasi, pada tahap penetapan (enactment) dilakukan penginterpretasian informasi antara subbagian media online dan pemberitaan dengan cara evaluasi informasi. Hasil evaluasi kemudian diperoleh kebijakan untuk menerima informasi dari sumber resmi seperti di website covid19.go.id, Kementerian Kesehatan (Kemenkes) atau informasi dari World Health Organization (WHO) untuk membuat konten informasi terkait Covid-19 di instagram Kemenkominfo.

"Subbagian media online pasti mengevaluasi sih, ennggak mungkin enggak, karena kan sebelum naik pasti dievaluasi dan setelah naik kayak bulanan juga kita akan ada evaluasi konten instagram apapun ya enggak hanya sekedar tentang Covid-19 aja, "'-Bonita

Untuk menghilangkan ambiguitas informasi khususnya informasi terkait Covid-19 di konten instagram Kemenkominfo, subbagian organisasi Kemenkominfo tidak langsung menerima informasi begitu saja. Subbagian media online membuat kebijakan untuk mengutip informasi dari subbagian pemberitaan atau sumber resmi terpercaya.

"Kebijakan dari subbagian media online terkait pembuatan konten kita paling yang penting tu sumbernya resmi dan jelas dan kita coba buat semenarik mungkin aja sih, "-Bonita

Sementara itu, subbagian pemberitaan tidak hanya berkoordinasi dengan pihak Kemenkominfo saja namun bekerja sama juga dengan pihak luar Kemenkominfo dalam menerima informasi. Namun, sebelum informasi tersebut dipublikasikan, langkah yang diambil subbagian pemberitaan yaitu melakukan konfirmasi kepada Dirjen Informasi Komunikasi Publik (IKP).

"Malah bukan dengan subbagian lain di humas saja tapi juga dengan beberapa kementerian dan juga lembaga lain yang memang berkaitan dengan penanganan Covid-19. Kalau sekarang sudah tersentral, jadi totally supporting kita di bawah back up untuk yang Media Center Komite Penanggulangan Covid-19 dan Pemulihan Ekonomi Nasional yang kebetulan kantornya di Kementerian Komunikasi dan Informatika, "-Taufiq

\section{Proses Organisasi Informasi: Penyeleksian (Selection)}

Proses seleksi informasi dilakukan subbagian media online dalam pencarian informasi tambahan di media eksternal khususnya instagram. Dalam pemilihan 
Christin Hani, Roswita Oktavianti: Proses Organisasi Informasi Covid-19 Pada Media Sosial Instagram Kementerian Komunikasi dan Informatika Republik Indonesia

informasi Kemenkominfo mengevaluasi dan menganalisis kembali informasi yang diterima dari sumber resmi terkait informasi Covid-19. Dari hasil evaluasi dan analisis, informasi dipilih untuk kepentingan pembuatan konten instagram terkait Covid-19. Sesuai dengan job desc, humas media online berwenang menangani media online di Kemenkominfo, dan saling berkoordinasi dengan subbagian pemberitaan dan yang lainnya.

"Subbagian media online hmm pasti mengevaluasi sih engga mungkin engga karna kan sebelum naik pasti dievaluasi dan setelah naik kayak bulanan juga kita akan ada evaluasi konten instagram apapun ya engga hanya sekedar tentang Covid-19 aja, "'-Bonita

Sedangkan subbagian pemberitaan hanya fokus melakukan evaluasi terhadap kriteria informasi yang sesuai dengan kebijakan informasi Kemenkominfo. Subbagian pemberitaan memprioritaskan informasi yang menyangkut soal pemanfaatan teknologi, aktivitas kampanye, dan berkaitan dengan pencapaian kinerja pemerintahan secara umum.

"Kita lakukan evaluasi itu dengan kriteria apakah memang beritanya selaras dengan kebijakan pemerintahan Kominfo, prioritasnya adalah menyangkut soal pemanfaatan teknologi kemudian juga ada aktivitas kampanye dan juga yang berkaitan dengan capaian dari kerja pemerintah secara umum,"'-Taufiq

Selanjutnya, memberikan data hasil rekapan mengenai kritik, saran, dan pendapat dari khalayak terkait pandangan mereka terhadap konten instagram Kemenkominfo yang merupakan informasi tambahan. Subbagian pemberitaan juga melakukan koordinasi dengan beberapa kementerian dan lembaga lain yang berkaitan dengan penanganan Covid-19. Akan tetapi, informasi yang diterima Kemenkominfo juga berada dibawah naungan komisi IKPJ dan komisi penanggulangan Covid-19 serta pemulihan ekonomi nasional.

\section{Proses Organisasi Informasi: Penyimpanan (Retention)}

Pada tahap terakhir ini, organisasi melakukan penyimpanan informasi pada tanggapan dari berbagai situasi. Informasi yang telah disimpan dapat dijadikan satu pada kesatuan informasi yang sudah ada untuk mengendalikan organisasi dan informasi tersebut akan digunakan untuk kasus serupa (dalam Destiana: 2019, 4143). Hal tersebut juga ditemukan dalam penelitian yang dilakukan Nindyasari (2014) yang mengumpulkan informasi dan Informasi yang disimpan tersebut akan digunakan kembali saat menangani kasus serupa. Sedangkan penelitian yang dilakukan Sihabuddin (2018) melakukan penyimpanan informasi yang akan digunakan dimasa yang akan datang. Informasi yang disimpan tersebut digabungkan pada satu kesatuan informasi yang sudah ada untuk menjalankan aktivitas organisasi.

Proses penyimpanan informasi yang telah diterima, tidak dikumpulkan saat proses penerimaan informasi, akan tetapi subbagian Kemenkominfo lebih fokus mengevaluasi informasi yang diterima dengan cara berdiskusi antar sesama subbagian maupun subbagian lainnya agar dapat mengurangi disinformasi. Setelah itu evaluasi tersebut disimpan dan akan digunakan untuk keperluan berorganisasi.

"Subbagian media online hmm pasti mengevaluasi sih engga mungkin engga karna kan sebelum naik pasti dievaluasi dan setelah naik kayak bulanan juga kita akan ada evaluasi konten instagram apapun ya engga hanya sekedar tentang Covid-19 aja, "'-Bonita 
Proses pengurangan ketidakpastian atau ambiguitas informasi oleh Kemenkominfo adalah siklus komunikasi yang saling terhubung antar subbagian di humas Kemenkominfo dalam mempublikasikan informasi yang dimuat dalam bentuk konten instagram di media sosial Kemenkominfo. Jika salah satu dari subbagian Kemenkominfo tidak bekerja sama dengan baik dalam hal mengurangi ketidakpastian informasi, maka proses seleksi informasi ambiguitas ini akan terjadi kegagalan dikarenakan penetapan, penyeleksian, dan penyimpanan informasi ini saling berhubungan.dengan teori informasi organisasi pada penelitian ini.

Selain itu pada penelitian ini juga mengaitkan pemanfaatan media digital dan komunikasi secara digital yang diterapkan Kemenkominfo untuk berkoordinasi saat pandemi Covid-19. Terjadi interaksi dalam penggunaan media digital yang merupakan kebutuhan sehari-hari para anggota organisasi di Kemenkominfo.

"Untuk koordinasi kadang ya, kadang tidak, selama pandemi, karena beberapa informasi yang sudah terpublish lewat website dan dishare lewat whatsapp (wa) itu sudah langsung bisa di publish clean atau istilahnya sudah boleh dipublish. Saya enggak tahu nih kalau misalkan kategori WA sharing diskusi grup itu juga termasuk koordinasi apa tidak, tapi yang jelas lebih dominan sifatnya adalah kita melakukan konfirmasi kepada temen-temen di Dirjen IKP ketika informasi akan dipublish atau tidak", -Taufiq

\section{Simpulan}

Hasil penelitian ini menunjukkan bahwa proses pengorganisasian informasi dilakukan oleh Kemenkominfo untuk meminimalisir ketidakjelasan informasi dalam jaringan. Proses organisasi informasi meliputi proses penetapan informasi oleh Kemenkominfo. Penginterpretasian informasi antara subbagian media online dan pemberitaan dengan cara evaluasi informasi. Hasil evaluasi kemudian diperoleh kebijakan untuk menerima informasi dari sumber resmi seperti di website covid19.go.id, Kementerian Kesehatan atau informasi dari World Health Organization untuk membuat konten informasi terkait Covid-19 di instagram Kemenkominfo.

Kedua, proses penyeleksian informasi yang dilakukan oleh Kemenkominfo pada pencarian informasi tambahan di media eksternal khususnya instagram. Dalam pemilihan informasi, Kemenkominfo mengevaluasi serta menganalisis kembali informasi yang diterima dari sumber resmi terkait informasi Covid-19. Dari hasil evaluasi dan analisis informasi dipilih untuk kepentingan pembuatan konten instagram terkait Covid-19. Ketiga, proses penyimpanan informasi yang telah diterima, tidak dikumpulkan saat proses penerimaan informasi, akan tetapi subbagian Kemenkominfo lebih fokus mengevaluasi informasi yang diterima dengan cara berdiskusi antar sesama subbagian maupun subbagian lainnya agar dapat mengurangi disinformasi. Setelah itu evaluasi tersebut disimpan dan akan digunakan untuk keperluan berorganisasi.

\section{Ucapan Terima Kasih}

Peneliti mengucapkan terima kasih kepada narasumber dari Kemenkominfo RI dan kepada teman-teman dekat peneliti serta pihak lainnya yang telah membantu dan mendukung peneliti selama proses penelitian ini berlangsung sampai dengan pembuatan jurnal pada penelitian ini. 
Christin Hani, Roswita Oktavianti: Proses Organisasi Informasi Covid-19 Pada Media Sosial Instagram Kementerian Komunikasi dan Informatika Republik Indonesia

\section{Daftar Pustaka}

Creswell, J. W. (2007). Qualitative Inquiry and research design: choosing among five approaches. Thousand Oaks London New Delhi: Sage Publication.

Destiana, E. (2019). Strategi Majalah Internal di PT.Garuda Indonesia (Pesero) tbk Berdasarkan Teori Informasi Organisasi: Studi Kasus pada Majalah View Tahun 2018. Bachelor Thesis, Universitas Multimedia Nusantara. https://kc.umn.ac.id/10697/, diunduh tanggal 12 Oktober 2020

Moleong Lexi J. (2009). Metode Penelitian Kualitatif. Edisi Revisi. Bandung: Remaja Rosdakarya

Nindyasari. (2014). Konstruksi Kebijakan Sistem Boarding Pass Di PT KAI (PERSERO) (Studi Deskriptif Kualitatif tentang Konstruksi Kebijakan Sistem Boarding Pass di PT KAI dengan Pendekatan Karl Weick). E-journal Universitas Atma Jaya Yogyakarta. http://ejournal.uajy.ac.id/6673/1/JURNAL.pdf, diunduh tanggal 17 Oktober 2020

Oktaviana, S \& Widayatmoko. (2018). Jaringan Komunikasi Antara Pimpinan dan Karyawan dalam Menumbuhkan Komitmen Karyawan di PT Digital Suplai Indonesia. Jurnal Koneksi, https://journal.untar.ac.id/index.php/koneksi/article/view/3936/2319, diunduh tanggal 8 Oktober 2020.

Ramadhan, Adhitya. (2020). Informasi penting yang perlu diketahui seputar Covid19. Diambil kembali dari kompas.id: https://kompas.id/baca/internasional/2020/03/31/informasi-penting-yangperlu-diketahui-seputar-covid-19/

Suswanto, B. (2016). Analisis Aliram Informasi Komunikasi Internal Dalam Implementasi Mobile Working Pada Perusahaan Media Penyedia Konten Internal Magazine (Studi Kasus di PT Tanair Media Seruni). Jurnal Media Komunikasi, Vol, 6(2). http://digilib.mercubuana.ac.id, diunduh tanggal 13 Oktober 2020

West, Richard \& Turner, Lynn H. (2009). Pengantar Teori Komunikasi: Analisis dan Aplikasi Edisi Ketiga. Jakarta: Salemba Humanika. 